Оськіна Ірина Сергіївна, магістр психології, ПрАТ «ВНЗ «МАУП», 02000, вул. Фрометівська, 2, м. Київ, Україна

ORCID: https://orcid.org/0000-0002-5144-8484

\title{
ПСИХОЛОГІЧНІ ОСОБЛИВОСТІ ЖІНКИ, ЯКА ВИХОВУЄ ДИТИНУ ВІД ПЕРШОГО ШЛЮБУ В НОВИХ ПОДРУЖНІХ СТОСУНКАХ
}

\begin{abstract}
Анотація
Ключові слова: жінка, матір, психологічні особливості жінки, шлюб, повторний шлюб, подружні стосунки, виховання, дитина

Постановка проблеми. При повторних шлюбах постає багато проблем, крім того, у повторному шлюбі люди знову стикаються 3 труднощами, які ускладнювали їх перший шлюб.

Аналіз останніх досліджень і публікацій. Сім'я та сімейні проблеми привертають пильну увагу спеціалістів. Проблема повторних шлюбів - це, насамперед, конфлікт між дитиною і «новим батьком», і в його формуванні або усунення важливу роль відіграє мати. Щоб утворилася нова сім'я, потрібен час, і часто цьому перешкоджають нереальні очікування.

Виклад основного матеріалу. В більшості, матері в другому шлюбі не виявляють щирих інтересів до того, що цікавить дитину від першого шлюбу, не оцінюють здібності дитини, встановлюють деяку, часто значну, психологічну дистанцію між собою i дитиною, недостатньо про неї піклуються. В ряді випадків, мати поводиться занадто авторитарно по відношенню до дитини, або, навпаки, контроль над діями дитини з боку матері практично відсутній. Майже половна досліджуваних жінок, якы перебувають у другому шлюбі, вважають свою дитину від першого шлюбу маленьким невдахою.
\end{abstract}


Висновки та перспективи подальших досліджень. Жінка повинна вміти аналізувати свою поведінку і вчасно звертатися за консультацією до психолога в разі необхідності. Інакше, дуже висока доля імовірності, що в новому шлюбі все піде по старому сценарію.

\section{Аннотация}

Оськина И. С., магистр психологии; ЧАО «ВУЗ «МАУП»; г. Киев, Украина. Психологические особенности женщины, которая воспитывает ребенка от первого брака в новых супружеских отношениях.

Ключевые слова: женщина, мать, психологические особенности женщины, брак, повторный брак, супружеские отношения, воспитание, ребенок.

Постановка проблемы. При повторных браках появляется много проблем, кроме того, в повторном браке люди вновь сталкиваются с трудностями, которые усложняли их первый брак.

Анализ последних исследований и публикаций. Семья и семейные проблемы привлекают пристальное внимание специалистов. Проблема повторных браков - это, прежде всего, конфликт между ребенком и «новым отцом», и в его формировании или устранении важную роль играет мать. Чтобы образовалась новая семья, нужно время, и часто этому препятствуют нереальные ожидания.

Изложение основного материала. В большинстве, матери во втором браке не проявляют искреннего внимания к тому, что интересует ребенка от первого брака, не оценивают способности ребенка, устанавливают некоторую, часто значительное, психологическую дистанцию между собой и ребенком, недостаточно о нем заботятся. В ряде случаев, мать ведет себя слишком авторитарно по отношению к ребенку, или, наоборот, контроль над действиями ребенка со стороны матери практически отсутствует. Почти половна исследуемых женщин, находящихся во втором браке, считают своего ребенка от первого брака маленьким неудачником. 
Выводы и перспективы дальнейших исследований. Женщина должна уметь анализировать свое поведение и вовремя обращаться за консультацией к психологу в случае необходимости. Иначе, очень высокая доля вероятности, что в новом браке все пойдет по старому сценарию.

\section{Annotation}

Os'kina I. S., Magister of Psychology; The Private Joint-Stock Company Higher Educational Institution Interregional Academy of Personnel Management; Kyiv, Ukraine. Psychological features of a woman who brings up a child from her first marriage in a new marital relationship.

Key words: woman, mother, psychological features of a woman, marriage, remarriage, matrimonial relations, upbringing, child.

Formulation of the problem. When remarriages appear many problems, in addition, in remarriage people again face difficulties that complicate their first marriage.

Analysis of recent research and publications. Family and family problems attract the close attention of specialists. The problem of remarriages is, first of all, the conflict between the child and the "new father", and the mother plays an important role in its formation or elimination. For a new family to be formed, time is needed, and often this is hampered by unrealistic expectations.

The presentation of the main material. In the majority, mothers in the second marriage do not show sincere attention to what interests the child from the first marriage, do not assess the child's abilities, establish some, often significant, psychological distance between themselves and the child, do not care enough about it. In some cases, the mother behaves too authoritarian in relation to the child, or, on the contrary, there is practically no control over the actions of the child by the mother. Almost half of the studied women in the second marriage consider their child from the first marriage a little loser.

Conclusions and prospects for further research. A woman should be able to analyze her behavior and consult a psychologist in time if necessary. Otherwise, 
a very high proportion of the likelihood that in a new marriage everything will go according to the previous scenario.

Ключові слова: жінка, матір, особливості жінки, шлюб, повторний шлюб, подружні стосунки, виховання, дитина

Постановка проблеми. Кількість розлучень в Україні порівняно з 90ми роками минулого століття зросла майже удвічі. Наскільки швидко жінка зможе адаптуватись у новому шлюбі залежить від їі емоційної зрілості, відповідальності за свої почуття та вчинки. У новому шлюбі виникають труднощі, тому жінці важливо знати себе, знати свої бажанні, ціннісні орієнтири, організувати своє життя за своїм задумом.

При повторних шлюбах постає багато проблем: як ростити i виховувати дітей від попередніх шлюбів, сплачувати й отримувати аліменти, вибудовувати стосунки 3 колишніми (дружиною, чоловіком). Крім того, у повторному шлюбі люди опиняються перед труднощами, які ускладнювали їх перший шлюб (егоїзм, пияцтво, відсутність порозуміння тощо), а також дублюються сексуальні проблеми.

Аналіз останніх досліджень і публікацій. Сім'я та сімейні проблеми привертають пильну увагу спеціалістів. Зокрема, такі питання як стабільність сім'ї, подружні затруднення, стійкість шлюбу, рівні сумісництва висвітлюють у своїх роботах С. Голод, М. Обозов, Ю. Олейник, В. Шевчук та ін. Сімейній психологіі та терапії присвячені роботи Е. Ейдеміллера та Е. Фрома. Питання жіночої психології розглядаються в роботах К. Юнга, 3. Фрейда, Д. Кемпбелла, І. Ялома, К. Естес, Р. Єфімкіної, М. Горкової. Висвітлення закономірностей виникнення й організації внутрішньосімейної діяльності та міжособистісної взаємодії також знайшли своє місце в певних роботах (Г. Андрєєва, О. Бодальов, С. Голод, Б. Гузиков, Л. Орбан-Лембрик, В. Столін та ін.). 
Успішність повторного шлюбу суттєво залежить від психологічної сумісності партнерів. Шлюби, що створені партнерами на грунті попереднього досвіду подружнього життя, мають типові психологічні особливості, як-от: домінування розрахунку, а не почуттів; порівняння нинішнього шлюбу з колишнім; протилежна організація; повторна адаптація.

Як вважає Т. Титаренко, творча особистість, на відміну від особистості незрілої, нетворчої може перетворити найтяжчі життєві обставини на плацдарм для формування нових технік життя, конструктивних життєвих стратегій. Вона не лише переживає неприємності, не лише страждає, а й сприймає їх як випробування, що загартовують, навчають, дають необхідний досвід [7, с. 48].

На думку Ковалева С.В. завадити щасливому сімейному життю у повторному шлюбі можуть глибокі суперечності: між старими і новими шлюбно-родинними настановами; між попереднім досвідом сімейного життя і новими стосунками; між різними, або й протилежними індивідуальними звичками подружньої взаємодії чоловіка та дружини; між подружньою та батьківською любов'ю в родинах із дитиною від першого шлюбу.

Якщо в повторному шлюбі люди постійно співставляють попередній i нинішній подружній досвід, виявляючи, що перший шлюб був більш вдалим, то психологічна адаптація чоловіка та дружини розгортається ускладнено [2, ст. 97]. На думку А. Н. Обозової, існує чотири аспекти подружньої сумісності, необхідність поділу яких, на іï думку, обгрунтована розходженням властивих їм критеріїв, закономірностей і проявів:

1) духовна сумісність - характеризує узгодженість компонентів поведінки партнерів: установок, ціннісних орієнтацій, потреб, інтересів, поглядів, оцінок, думок;

2) персональна сумісність - характеризує відповідність структурнодинамічних особливостей партнерів: властивостей темпераменту, характеру, емоційно-вольової сфери. Один із критеріїв персональної сумісності безконфліктне розподіл міжособистісних ролей, а основна закономірність 
цього аспекту сумісності подружжя - додатковість структурних характеристик партнерів;

3) сімейно-побутова сумісність - функціональні особливості шлюбних партнерів: узгодженість уявлень про функції сім'ї та відповідному укладі, узгодженість рольових очікувань і домагань при реалізації цих функцій. Основним критерієм є ефективність виховання дітей;

4) фізіологічна сумісність - основним критерієм $є$ сексуальна сумісність, тобто задоволеність від фізіологічної близькості [3, с. 68].

Роджерс вважав, що постійність взаємовідносин між чоловіком і жінкою збережеться в тій мірі, в якій ці взаємини задовольняють емоційні, психологічні, інтелектуальні та фізичні потреби партнерів [5, с. 205].

Як вказує С. І. Голод, повторні шлюби супроводжує клубок протиріч, особливо в тих випадках, коли жінка, котра має дитину, народжує i в повторному шлюбі. Межі сім’ї стають розпливчастими, характер же відносин жінки 3 колишнім «чоловіком-батьком» і актуальним «чоловіком-батьком», дитини 3 матір’ю, батьком і вітчимом, зведених братів (сестер) між собою невизначеним і заплутаним [1,c.58].

Проблема повторних шлюбів - це, насамперед, конфлікт між дитиною і «новим батьком», і в його формуванні або усунення важливу роль відіграє мати. Для дитини створення нової сім’ї $\epsilon$ психологічною травмою i, виходячи заміж, жінка повинна про це пам'ятати. Завдяки своїй інтуїції жінка зможе знайти індивідуальний підхід і до свого чада і до чоловіка, але перший час вона, скоріше за все, буде як між двох вогнів.

Як вважає Голод С.І., щоб утворилася нова сім'я, потрібен час, іноді тривалий час, i часто цьому перешкоджають нереальні очікування. Найбільша помилка - вважати, що всі полюблять один одного 3 самого початку [1, ст.187].

Зазвичай сімейні відносини у повторному шлюбі розвиваються таким чином, проходячи ряд закономірних стадій: 
- Стадія мрій: вам здається, що все піде легко і просто. Ви щасливі, що у ваших дітей з'явиться новий тато, брати і сестри.

- Стадія псевдоасиміляції. Ви намагаєтеся все робити так, як вам мріялося, але виходить зовсім не те, чого ви очікували. Фантазії не витримують зіткнення з реальністю.

- Стадія оцінки реального стану речей. Ви розумієте, що не все складається, як треба, і треба щось зробити. Вас раптово починає дратувати, коли ваша пасербиця сідає в машині на переднє місце поруч з батьком, замість того щоб сісти ззаду. Напруженість у відносинах зростає, а іноді виливається в бурхливі сцени.

- Стадія мобілізації. На цій стадії члени сім’ї починають виходити 3 загальмованого стану і висловлювати, що їх не влаштовує. Чекайте палких суперечок.

- Стадія дій. Батьки починають визначати обов'язки 3 ведення домашнього господарства, разом приймають рішення, як задовольнити складне переплетення потреб усіх членів нової сім'ї.

- Стадія створення контактів. Відбувається поглиблення взаємозв'язків між нерідними батьками і нерідними дітьми.

- Стадія дозволу. Тепер ви всі добре один одного знаєте, встановлено нові правила, і всі виконують їх. Ви стали згуртованою сім'єю [4, с.78].

На думку Столярчук О. А., построзлучна ситуація може бути ускладнена різними обставинами. За довгий час сумісного життя, батьки й діти обростають сімейними жартами та сленгом, які можуть стати після розлучення недоречними. Майже в кожній сім'ї формуються свої ритуали, традиції. Усе це треба вибудовувати наново, щоб уникнути непередбачуваних недоречностей [6, с.78].

Виклад основного матеріалу. За допомогою таблиці 1 представимо зведені результати за підшкалою «Сімейні конфлікти» для жінок у другому шлюбі IЕГ та першому шлюбі II ЕГ. Як бачимо з табл. 1 для жінок I ЕГ: у 13 3 досліджуваних жінок у другому шлюбі низька оцінка сімейних конфліктів, 
у 6 досліджуваних жінок у другому шлюбі - висока оцінка сімейних конфліктів, 6 жінок мають мінімальну оцінку сімейних конфліктів і у 13 жінок середні показники сімейних конфліктів.

Таблиця 1.

Зведені результати за підшкалою «Сімейні конфлікти» для жінок у 1-му та 2-му шлюбі

\begin{tabular}{|c|c|c|c|c|c|}
\hline \multirow{2}{*}{$\begin{array}{l}\text { Показники } \\
\text { сімейні } \\
\text { конфлікти }\end{array}$} & \multicolumn{2}{|c|}{ I E } & \multicolumn{2}{|c|}{ II EГ } & \multirow{2}{*}{$\begin{array}{c}\text { t-критерій } \\
\text { Стьюдента } \\
\text { для } \\
\text { непов'язаних } \\
\text { сукупностей } \\
\text { (tкрит=1,992, f=76 } \\
\text { при } \alpha=0,05)\end{array}$} \\
\hline & $\begin{array}{c}\text { Абс. } \\
\text { кількість }\end{array}$ & $\%$ & $\begin{array}{c}\text { Абс. } \\
\text { кількість }\end{array}$ & $\%$ & \\
\hline $\begin{array}{l}\text { Висока } \\
\text { оцінка }\end{array}$ & 6 & 15,8 & 8 & 20,0 & 14,14 \\
\hline $\begin{array}{l}\text { Середня } \\
\text { оцінка }\end{array}$ & 13 & 34,2 & 16 & 40,0 & 21,21 \\
\hline $\begin{array}{l}\text { Низька } \\
\text { оцінка }\end{array}$ & 13 & 34,2 & 15 & 37,5 & 14,14 \\
\hline $\begin{array}{l}\text { Мінімальна } \\
\text { оцінка }\end{array}$ & 6 & 15,8 & 1 & 2,5 & 35,36 \\
\hline Всього & 38 & 100 & 40 & 100 & \\
\hline
\end{tabular}

У жінок у першому шлюбі маємо такі показники: у 8-ми жінок висока оцінка сімейних конфліктів. У 16 жінок виявилась середня оцінка за шкалою «сімейні конфлікти», у 15 жінок у першому шлюбі маємо низьку оцінку конфліктів у родині і у однієї жінки мінімальна.

Наступна ознака, яку було досліджено,- «Обмеженість інтересів жінки». В таблиці 2 представлені зведені результати дослідження для IЕГ (жінок у другому шлюбі) та IIЕГ (жінок у першому шлюбі).

3 таблиці 2 бачимо, що у більшої кількості жінок I ЕГ, які приймали участь у дослідженні, низька оцінка обмеженості інтересів турботами сім'ї. Таких жінок 19. У 6 жінок висока оцінка обмеженості інтересів, у 3 жінок мінімальна обмеженість інтересів, у 10 жінок, що випробовувались, середні значення за ознакою обмеженість інтересів. У жінок II ЕГ маємо такі 
показники за ознакою «обмеженість інтересів»: у 5 жінок - висока оцінка, у 15 жінок маємо середню оцінку, у 18 жінок отримали низьку оцінку за цією ознакою, у 2 жінок мінімальна оцінка.

Таблиця 2.

Зведені результати за ознакою «Обмеженість інтересів жінки рамками сім'ї, турботами виключно сім'ї» для ІЕГ та ІІЕГ

\begin{tabular}{|c|c|c|c|c|c|}
\hline \multirow{2}{*}{$\begin{array}{l}\text { Показники } \\
\text { обмеженість } \\
\text { інтересів }\end{array}$} & \multicolumn{2}{|c|}{ I EГ } & \multicolumn{2}{|c|}{ II EГ } & \multirow{2}{*}{$\begin{array}{c}\text { t-критерій } \\
\text { Стьюдента для } \\
\text { непов'язаних } \\
\text { сукупностей } \\
\text { (tкрит=1,992, f=76 при } \\
\alpha=0,05)\end{array}$} \\
\hline & $\begin{array}{c}\text { Абс. } \\
\text { кількість }\end{array}$ & $\%$ & $\begin{array}{c}\text { Абс. } \\
\text { кількість }\end{array}$ & $\%$ & \\
\hline Висока оцінка & 6 & 15,8 & 5 & 12,5 & 7,07 \\
\hline Середня оцінка & 10 & 26,3 & 15 & 37,5 & 35,36 \\
\hline Низька оцінка & 19 & 50 & 18 & 47,4 & 7,07 \\
\hline $\begin{array}{l}\text { Мінімальна } \\
\text { оцінка }\end{array}$ & 3 & 7,9 & 2 & 5,0 & 7,07 \\
\hline Всього & 38 & 100 & 40 & 100 & \\
\hline
\end{tabular}

Далі було проаналізовано ознаку «Відчуття самопожертви». У таблиці 3 наводяться зведені результати за підшкалою «Відчуття самопожертви».

Таблиця 3.

Зведені результати за підшкалою «Відчуття самопожертви» за методикою PARI для жінок I ЕГ (другий шлюб) та II ЕГ (перший шлюб)

\begin{tabular}{|c|c|c|c|c|c|}
\hline \multirow{2}{*}{$\begin{array}{l}\text { Показники } \\
\text { відчуття } \\
\text { самопожертви }\end{array}$} & \multicolumn{2}{|c|}{ I E $\Gamma$} & \multicolumn{2}{|c|}{ II EГ } & \multirow{2}{*}{$\begin{array}{c}\text { t-критерій } \\
\text { Стьюдента для } \\
\text { непов'язаних } \\
\text { сукупностей } \\
\text { (tкрит=1,992, f=76 при } \\
\alpha=0,05)\end{array}$} \\
\hline & $\begin{array}{c}\text { Аб. } \\
\text { кіл-ть }\end{array}$ & $\%$ & Аб.кіл-ть & $\%$ & \\
\hline Висока оцінка & 4 & 10,53 & 6 & 15,0 & 14,14 \\
\hline $\begin{array}{l}\text { Середня } \\
\text { оцінка }\end{array}$ & 14 & 36,84 & 21 & 52,5 & 49,50 \\
\hline Низька оцінка & 15 & 39,47 & 11 & 27,5 & 28,28 \\
\hline $\begin{array}{l}\text { Мінімальна } \\
\text { оцінка }\end{array}$ & 5 & 13,16 & 2 & 5,0 & 21,21 \\
\hline Всього & 38 & 100 & 40 & 100 & \\
\hline
\end{tabular}


Отже, з усіх досліджуваних жінок I ЕГ у 15 виявилась низька оцінка за ознакою «відчуття самопожертви», 4 жінки мають високу оцінку і 5 жінок мінімальну. Середню оцінку виявили у 14 досліджуваних жінок.

У жінок II ЕГ маємо такі показники: у 6 жінок висока оцінка за ознакою «відчуття самопожертви», у 21 жінки виявилась середня оцінка, маємо низьку оцінку у 11 досліджуваних жінок, мінімальна оцінка у 5 жінок.

Наступна ознака «Над-авторитет батьків». У таблиці 4 наведемо зведені результати за цією ознакою для жінок I ЕГ та ІІ ЕГ.

Таблиця 4.

Зведені результати за ознакою «Над-авторитет батьків» за методикою PARI для жінок I ЕГ та II EГ

\begin{tabular}{|c|c|c|c|c|c|}
\hline \multirow{2}{*}{$\begin{array}{l}\text { Показники } \\
\text { Над- } \\
\text { авторитет } \\
\text { батьків }\end{array}$} & \multicolumn{2}{|c|}{ I E } & \multicolumn{2}{|c|}{ II EГ } & \multirow{2}{*}{$\begin{array}{c}\text { t-критерій } \\
\text { Стьюдента для } \\
\text { непов'язаних } \\
\text { сукупностей } \\
\text { (tкрит=1,992, f=76 при } \\
\alpha=0,05) \\
\end{array}$} \\
\hline & $\begin{array}{c}\text { Абс. } \\
\text { кількість }\end{array}$ & $\%$ & $\begin{array}{c}\text { Абс. } \\
\text { кількість }\end{array}$ & $\%$ & \\
\hline $\begin{array}{l}\text { Висока } \\
\text { оцінка }\end{array}$ & 5 & 10,5 & 6 & 15,0 & 7,07 \\
\hline $\begin{array}{l}\text { Середня } \\
\text { оцінка }\end{array}$ & 15 & 36,9 & 21 & 52,5 & 42,43 \\
\hline $\begin{array}{l}\text { Низька } \\
\text { оцінка }\end{array}$ & 14 & 39,5 & 11 & 27,5 & 21,21 \\
\hline $\begin{array}{l}\text { Мінімальна } \\
\text { оцінка }\end{array}$ & 4 & 13,2 & 2 & 5,0 & 14,14 \\
\hline Всього & 38 & 100 & 40 & 100 & \\
\hline
\end{tabular}

Для жінок I ЕГ маємо наступні показники за ознакою «Над-авторитет батьків»: у 5 жінок висока оцінка за цією ознакою, у 15 жінок маємо середню оцінку, у 14 жінок отримали низьку оцінку і у 4 жінок мінімальна оцінка.

Для жінок II ЕГ одержані такі результати: у 6 жінок маємо високу оцінку за ознакою «Над-авторитет батьків», у 21 жінки виявилась середня оцінка, у 11 жінок отримали низьку оцінку і у 2 жінок мінімальна оцінка.

Проаналізуємо результати за ознакою «Незадоволеність роллю господині» за допомогою таблиці 5. 
Для жінок I ЕГ маємо: у 12 жінок низька оцінка незадоволеністю роллю господині, у 7 жінок висока оцінка незадоволеністю роллю господині, у 4 жінок мінімальна незадоволеність роллю господині, а 15 досліджуваних жінок отримали середні оцінки. Отже, в найбільшої кількості жінок середня оцінка незадоволеністю роллю господині.

Таблиця 5.

Зведені результати за ознакою «Незадоволеність роллю господині» за методикою PARI для жінок I EГ та II EГ

\begin{tabular}{|c|c|c|c|c|c|}
\hline \multirow{2}{*}{$\begin{array}{l}\text { Показники } \\
\text { «незадоволеність } \\
\text { роллю } \\
\text { господині» }\end{array}$} & \multicolumn{2}{|c|}{ I EГ } & \multicolumn{2}{|c|}{ II EГ } & \multirow{2}{*}{$\begin{array}{c}\text { t-критерій } \\
\text { Стьюдента для } \\
\text { непов' язаних } \\
\text { сукупностей } \\
\text { (tкрит }=1,992, \mathrm{f}=76 \\
\text { при } \alpha=0,05)\end{array}$} \\
\hline & $\begin{array}{c}\text { Абс. } \\
\text { кількість }\end{array}$ & $\%$ & $\begin{array}{c}\text { Абс. } \\
\text { кількість }\end{array}$ & $\%$ & \\
\hline Висока оцінка & 7 & 18,4 & 5 & 12,5 & 14,14 \\
\hline Середня оцінка & 15 & 39,5 & 17 & 42,5 & 14,14 \\
\hline Низька оцінка & 12 & 31,6 & 13 & 32,5 & 7,07 \\
\hline $\begin{array}{l}\text { Мінімальна } \\
\text { оцінка }\end{array}$ & 4 & 10,5 & 5 & 12,5 & 7,07 \\
\hline Всього & 38 & 100 & 40 & 100 & \\
\hline
\end{tabular}

Для жінок II ЕГ отримали такі показники: у 5 жінок висока оцінка за ознакою «незадоволеність роллю господині», у 17 жінок середня оцінка за цією ознакою, у 13 жінок одержали низьку оцінку і у 5 жінок мінімальна оцінка.

Наступна ознака, яка досліджувалася - «Байдужість чоловіка». Результати наведені у таблиці 6.

За ознакою «Байдужість чоловіка», для жінок I ЕГ маємо показники: у 16 жінок, що випробовувались, середня оцінка байдужості чоловіка, у 15 жінок низька оцінка байдужості чоловіка і у 2 жінок мінімальна оцінка байдужості чоловіка. У 5 \% всіх випробовуваних жінок отримали високі оцінки за ознакою «Байдужість чоловіка». 
За ознакою «Байдужість чоловіка» для жінок II ЕГ маємо показники: у 3 жінок висока оцінка за цією ознакою, у 24 жінок виявилась середні оцінка, у 8 жінок маємо низьку оцінку і у 5 жінок мінімальна оцінка.

Таблиця 6.

Зведені результати за ознакою «Байдужість чоловіка» за методикою PARI для жінок I EГ та II EГ

\begin{tabular}{|c|c|c|c|c|c|}
\hline \multirow{2}{*}{$\begin{array}{l}\text { Показники } \\
\text { «байдужість } \\
\text { чоловіка» }\end{array}$} & \multicolumn{2}{|c|}{ I E } & \multicolumn{2}{|c|}{ II EГ } & \multirow{2}{*}{$\begin{array}{c}\text { t-критерій } \\
\text { Стьюдента для } \\
\text { непов'язаних } \\
\text { сукупностей } \\
\text { (tкрит }=1,992, \mathrm{f}=76 \\
\text { при } \alpha=0,05)\end{array}$} \\
\hline & $\begin{array}{c}\text { Абс. } \\
\text { кількість }\end{array}$ & $\%$ & $\begin{array}{c}\text { Абс. } \\
\text { кількість }\end{array}$ & $\%$ & \\
\hline Висока оцінка & 5 & 13,2 & 3 & 7,5 & 14,14 \\
\hline $\begin{array}{l}\text { Середня } \\
\text { оцінка }\end{array}$ & 16 & 42,1 & 24 & 60,0 & 56,57 \\
\hline Низька оцінка & 15 & 39,5 & 8 & 20,0 & 49,50 \\
\hline $\begin{array}{l}\text { Мінімальна } \\
\text { оцінка }\end{array}$ & 2 & 5,3 & 5 & 12,5 & 21,21 \\
\hline Всього & 38 & 100 & 40 & 100 & \\
\hline
\end{tabular}

Отримані результати за ознакою «Домінування матері» представимо за допомогою таблиці 7 для жінок I ЕГ та II ЕГ.

Таблиця 7.

Зведені результати за ознакою «Домінування матері» за методикою PARI для жінок I ЕГ та II ЕГ

\begin{tabular}{|c|c|c|c|c|c|}
\hline \multirow{2}{*}{$\begin{array}{l}\text { Показники } \\
\text { «домінування } \\
\text { матері» }\end{array}$} & \multicolumn{2}{|c|}{ I EГ } & \multicolumn{2}{|c|}{ II EГ } & \multirow{2}{*}{$\begin{array}{c}\text { t-критерій } \\
\text { Стьюдента для } \\
\text { непов'язаних } \\
\text { сукупностей } \\
\text { (tкрит }=1,992, \mathrm{f}=76 \\
\text { при } \alpha=0,05)\end{array}$} \\
\hline & $\begin{array}{c}\text { Абс. } \\
\text { кількість }\end{array}$ & $\%$ & $\begin{array}{c}\text { Абс. } \\
\text { кількість }\end{array}$ & $\%$ & \\
\hline Висока оцінка & 10 & 26,3 & 7 & 20,0 & 21,21 \\
\hline Середня оцінка & 15 & 39,5 & 19 & 40,0 & 28,28 \\
\hline Низька оцінка & 13 & 34,2 & 12 & 32,5 & 7,07 \\
\hline $\begin{array}{l}\text { Мінімальна } \\
\text { оцінка }\end{array}$ & 0 & 0,0 & 2 & 7,5 & 14,14 \\
\hline Всього & 38 & 100 & 40 & 100 & \\
\hline
\end{tabular}


За ознакою «Домінування матері» для жінок I ЕГ маємо: у 10 жінок, що приймали участь у дослідженні, висока оцінка, у 13 жінок бачимо низьку оцінку домінування матері. Середня оцінка за ознакою домінування у 15 жінок.

За ознакою «Домінування матері» для жінок II ЕГ одержали: у 7 жінок висока оцінка за цією ознакою, у 19 жінок виявилась середня оцінка, у 12 жінок низька оцінка, у 2 жінок мінімальна оцінка.

Було проведено сімейний тест для жінок. Представимо зведені результати дослідження за сімейним тестом для жінок за допомогою таблиці 8 для жінок I ЕГ та II ЕГ.

Отримали такі результати за сімейним тестом для жінок I ЕГ: 3 усіх досліджених у 15 опитуваних жінок виявились дисгармонічні відносини 3 чоловіком, у 23 жінок отримали гармонійні стосунки з чоловіком за сімейним тестом для жінок.

Таблиця 8.

\section{Зведені результати дослідження за сімейним тестом} для жінок I ЕГ та II ЕГ

\begin{tabular}{|c|c|c|c|c|c|}
\hline \multirow[t]{2}{*}{ Показники } & \multicolumn{2}{|c|}{$\mathrm{IE}$ E } & \multicolumn{2}{|c|}{ II EГ } & \multirow{2}{*}{$\begin{array}{c}\text { t-критерій } \\
\text { Стьюдента для } \\
\text { непов'язаних } \\
\text { сукупностей } \\
\text { (tкрит }=1,992, \mathrm{f}=76 \\
\text { при } \alpha=0,05)\end{array}$} \\
\hline & $\begin{array}{c}\text { Абс. } \\
\text { кількість }\end{array}$ & $\%$ & $\begin{array}{c}\text { Абс. } \\
\text { кількість }\end{array}$ & $\%$ & \\
\hline Гармонійні & 23 & 60,5 & 26 & 65,0 & 21,21 \\
\hline Дисгармонійні & 15 & 39,5 & 14 & 35,0 & 7,07 \\
\hline Всього & 38 & 100 & 40 & 100 & \\
\hline
\end{tabular}

Результати для жінок за сімейним тестом II ЕГ: у 26 жінок виявились гармонійні відносини з чоловіками, у 14 маємо дисгармонійні відносини.

Проводився тест «Стабільність шлюбу» для жінок. У таблиці 9 приведемо зведені результати за цим тестом для жінок I ЕГ та ІІ ЕГ.

За тестом «Стабільність шлюбу», для жінок I ЕГ виявилось, що в більшості опитуваних жінок (19) шлюб виявився стабільним, тобто можна 
говорити про високий рівень взаєморозуміння в сім'ї і рівною позитивною атмосферою. У 16 жінок у стосунках з чоловіками можна говорити про деяку напруженість у відносинах. У однієї жінки шлюб на межі руйнування і тільки спільне бажання подружжя може щось змінити. У двох жінок, що проходили тестування, шлюб виявився щасливим.

Таблиця 9.

\section{Зведені результати за тестом «Стабільність шлюбу» для жінок I ЕГ та II ЕГ}

\begin{tabular}{|c|c|c|c|c|c|}
\hline \multirow[t]{2}{*}{ Показники } & \multicolumn{2}{|c|}{$\mathrm{IE}$} & \multicolumn{2}{|c|}{ II EГ } & \multirow{2}{*}{$\begin{array}{c}\text { t-критерій } \\
\text { Стьюдента для } \\
\text { непов'язаних } \\
\text { сукупностей } \\
\text { (tкрит }=1,992, \mathrm{f}=76 \\
\text { при } \alpha=0,05)\end{array}$} \\
\hline & $\begin{array}{c}\text { Абс. } \\
\text { кількість }\end{array}$ & $\%$ & $\begin{array}{c}\text { Абс. } \\
\text { кількість }\end{array}$ & $\%$ & \\
\hline руйнування & 1 & 2,6 & 2 & 5,0 & 7,07 \\
\hline напруження & 16 & 42,1 & 14 & 35,0 & 14,14 \\
\hline стабільний & 19 & 50 & 20 & 50,0 & 7,97 \\
\hline щасливий & 2 & 5,3 & 4 & 10,0 & 14,14 \\
\hline Всього & 38 & 100 & 40 & 100 & \\
\hline
\end{tabular}

За тестом стабільність шлюбу для жінок II ЕГ виявилося, що в 20 жінок стабільний шлюб. У 2 жінок шлюб на межі руйнування, в 14 жінок спостерігається напруженість у відносинах. У 4 жінок виявився щасливий шлюб.

Тест-опитувальник батьківського ставлення (ОРО), автори А.Я.Варга, В.В.Століна, являє собою методику для діагностики батьківського відношення у матерів, батьків, опікунів і т.д., що звертаються за психологічною допомогою з питань виховання дітей і спілкування з ними.

Результати опитування виражаються в п'яти шкалах: прийняттявідторгнення, соціальна бажаність поведінки дитини, симбіоз (відсутність дистанції між батьком і дитиною), авторитарний контроль, ставлення до невдач дитини. 
Було отримано результати за тестом по шкали «прийняття відторгнення». За допомогою таблиці 10 наведемо отримані зведені результати.

Таблиця 10.

Зведені результати за шкалою «Прийняття - відторгнення» за тестом опитувальником батьківського ставлення (ОРО), автори А. Я. Варга, В. В. Століна, для жінок I ЕГ та жінок II ЕГ

\begin{tabular}{|c|c|c|c|c|c|}
\hline \multirow[t]{2}{*}{ Показники } & \multicolumn{2}{|c|}{ I EГ } & \multicolumn{2}{|c|}{ II EГ } & \multirow{2}{*}{$\begin{array}{c}\text { t-критерій } \\
\text { Стьюдента для } \\
\text { непов'язаних } \\
\text { сукупностей } \\
\text { (tкрит }=1,992, \mathrm{f}=76 \\
\text { при } \alpha=0,05)\end{array}$} \\
\hline & $\begin{array}{c}\text { Абс. } \\
\text { кількість }\end{array}$ & $\%$ & $\begin{array}{c}\text { Абс. } \\
\text { кількість }\end{array}$ & $\%$ & \\
\hline Високі & 10 & 26,3 & 21 & 52,5 & 77,78 \\
\hline Середні & 9 & 23,7 & 14 & 35,0 & 35,36 \\
\hline Низькі & 19 & 50,0 & 5 & 12,5 & 98,99 \\
\hline Всього & 38 & 100 & 40 & 100 & \\
\hline
\end{tabular}

Як бачимо з табл. 10, у 10 жінок I ЕГ високі показники прийняття дитини за шкалою «прийняття - відторгнення». В 9 жінок середні показники, і в 19 - низькі показники прийняття дитини.

Для жінок II ЕГ маємо такі результати за шкалою «прийняття відторгнення»: у 21 жінки високі бали прийняття дитини, у 14 жінок середні показники прийняття і у 5 жінок маємо низькі показники прийняття дитини.

Наступна шкала, за якою було здійснено аналіз, шкала «Кооперація». У таблиці 11 наведені зведені результати за цією шкалою.

Для жінок I ЕГ маємо такі результати за шкалою «Кооперація»: у 13 досліджуваних жінок високі бали за шкалою «Кооперація». У 8 жінок середні бали, у 17 жінок - низькі бали. Отже, виявилося, що в більшості дорослі не виявляють щиру цікавість до того, що цікавить дитину, не оцінюють здібності дитини. Для жінок II ЕГ отримали за шкалою «Кооперація»: у 18 жінок високі оцінки, у 12 жінок середні оцінки за цією шкалою і у 10 жінок низькі оцінки. 
Таблиця 11.

Зведені результати за шкалою «Кооперація» за тестом опитувальником батьківського ставлення (ОРО), автори А.Я.Варга, В.В.Століна для жінок I ЕГ та II ЕГ

\begin{tabular}{|c|c|c|c|c|c|}
\hline \multirow[t]{2}{*}{ Показники } & \multicolumn{2}{|c|}{ I EГ } & \multicolumn{2}{|c|}{ II EГ } & \multirow{2}{*}{$\begin{array}{c}\text { t-критерій } \\
\text { Стьюдента для } \\
\text { непов'язаних } \\
\text { сукупностей } \\
\text { (tкрит }=1,992, \mathrm{f}=76 \\
\text { при } \alpha=0,05)\end{array}$} \\
\hline & $\begin{array}{c}\text { Абс. } \\
\text { кількість }\end{array}$ & $\%$ & $\begin{array}{c}\text { Абс. } \\
\text { кількість }\end{array}$ & $\%$ & \\
\hline високі & 13 & 34,2 & 18 & 45,0 & 35,36 \\
\hline середні & 8 & 21,1 & 12 & 30,0 & 28,28 \\
\hline низькі & 17 & 44,7 & 10 & 25,0 & 49,50 \\
\hline Всього & 38 & 100 & 40 & 100 & \\
\hline
\end{tabular}

представлені у таблиці 12 для жінок I ЕГ та II ЕГ. Як видно з таблиці 12, що за шкалою «Симбіоз» для жінок I ЕГ у 15 дітей жінок, середні бали, тобто дорослий встановлює деяку психологічну дистанцію між собою і дитиною. У 17 дітей, які брали участь у дослідженні, низькі бали, це означає, що дорослий встановлює значну психологічну дистанцію між собою і дитиною, мало про нього піклується. У 6 дітей маємо високі бали, тобто дорослий не встановлює психологічну дистанцію між собою і дитиною.

Таблиця 12.

Зведені результати за шкалою «Симбіоз» за тестом опитувальником батьківського ставлення (ОРО), автори А. Я. Варга, В. В. Століна, для жінок I ЕГ та II ЕГ

\begin{tabular}{|c|c|c|c|c|c|}
\hline \multirow[t]{2}{*}{ Показники } & \multicolumn{2}{|c|}{ I E $\Gamma$} & \multicolumn{2}{|c|}{ II EГ } & \multirow{2}{*}{$\begin{array}{c}\text { t-критерій } \\
\text { Стьюдента для } \\
\text { непов'язаних } \\
\text { сукупностей } \\
\text { (tкрит }=1,992, \mathrm{f}=76 \\
\text { при } \alpha=0,05)\end{array}$} \\
\hline & $\begin{array}{c}\text { Абс. } \\
\text { кількість }\end{array}$ & $\%$ & $\begin{array}{c}\text { Абс. } \\
\text { кількість }\end{array}$ & $\%$ & \\
\hline високі & 6 & 15,8 & 9 & 22,5 & 21,21 \\
\hline середні & 15 & 39,5 & 18 & 45,0 & 21,21 \\
\hline низькі & 17 & 44,7 & 13 & 32,5 & 28,28 \\
\hline Всього & 38 & 100 & 40 & 100 & \\
\hline
\end{tabular}


За шкалою «Симбіоз», для жінок II ЕГ маємо такі результати: у 9 високі оцінки за цією шкалою, у 18 жінок середні оцінки, і у 13 жінок виявилися низькі оцінки.

За шкалою «Контроль» отримані результати занесли у таблицю 13.

Таблиця 13.

Зведені результати за шкалою «Контроль» за тестом опитувальником батьківського ставлення (ОРО), автори А.Я.Варга, В.В.Століна для жінок I ЕГ та II ЕГ

\begin{tabular}{|c|c|c|c|c|c|}
\hline \multirow[t]{2}{*}{ Показники } & \multicolumn{2}{|c|}{ I E Г } & \multicolumn{2}{|c|}{ II EГ } & \multirow{2}{*}{$\begin{array}{c}\text { t-критерій } \\
\text { Стьюдента для } \\
\text { непов'язаних } \\
\text { сукупностей } \\
\text { (tкрит }=1,992, \mathrm{f}=76 \\
\text { при } \alpha=0,05)\end{array}$} \\
\hline & $\begin{array}{c}\text { Абс. } \\
\text { кількість }\end{array}$ & $\%$ & $\begin{array}{c}\text { Абс. } \\
\text { кількість }\end{array}$ & $\%$ & \\
\hline високі & 13 & 34,2 & 8 & 20,0 & 35,36 \\
\hline середні & 17 & 44,7 & 26 & 65,0 & 63,64 \\
\hline низькі & 8 & 21,1 & 6 & 15,0 & 14,14 \\
\hline Всього & 38 & 100 & 40 & 100 & \\
\hline
\end{tabular}

Для жінок I ЕГ за шкалою «Контроль»: у 17 жінок, які проходили тестування, середній бал за шкалою «Контроль». Тобто, дорослий поводиться не занадто авторитарно по відношенню до дитини. $\quad$ У 13 жінок вийшли високі бали, тобто, дорослий поводиться занадто авторитарно по відношенню до дитини. У 8 опитаних жінок, - низькі бали, це свідчить про те, що контроль над діями дитини з боку дорослого практично відсутній. Для жінок II ЕГ за шкалою «Контроль» результати такі: у 8 жінок високі оцінки, у 26 жінок маємо середні оцінки і у 6 жінок отримали низькі оцінки. За шкалою «Ставлення до невдач» також було отримано зведені результати, що були занесені у таблицю 14. Для жінок I ЕГ за шкалою «Ставлення до невдач»: високі бали були одержані у 15 жінок, тобто вони вважають дитину маленьким невдахою. У 11 жінок, які брали участь в опитуванні, були одержані середні бали, тобто дорослий оптимально ставиться до невдач дитини. У 12 жінок отримали низькі бали, тобто невдачі дитини мати вважає випадковими і вірить в неї. 
Таблиця 14.

Зведені результати за шкалою «Ставлення до невдач» за тестом опитувальником батьківського ставлення (ОРО), автори А.Я.Варга, В.В.Століна для жінок I ЕГ та ІІ ЕГ

\begin{tabular}{|c|c|c|c|c|c|}
\hline \multirow[t]{2}{*}{ Показники } & \multicolumn{2}{|c|}{ I E $\Gamma$} & \multicolumn{2}{|c|}{ II EГ } & \multirow{2}{*}{$\begin{array}{c}\text { t-критерій } \\
\text { Стьюдента для } \\
\text { непов'язаних } \\
\text { сукупностей } \\
\text { (tкрит }=1,992, \mathrm{f}=76 \\
\text { при } \alpha=0,05)\end{array}$} \\
\hline & $\begin{array}{c}\text { Абс. } \\
\text { кількість }\end{array}$ & $\%$ & $\begin{array}{c}\text { Абс. } \\
\text { кількість }\end{array}$ & $\%$ & \\
\hline високі & 15 & 39,5 & 12 & 30,0 & 21,21 \\
\hline середні & 11 & 28,7 & 19 & 47,5 & 56,57 \\
\hline низькі & 12 & 31,6 & 9 & 22,5 & 21,21 \\
\hline Всього & 38 & 100 & 40 & 100 & \\
\hline
\end{tabular}

Для жінок I ЕГ за шкалою «Ставлення до невдач»: високі бали в 12 жінок. Середні бали в 19 жінок, низькі бали в 9 жінок.

Було проведено опитування задоволеності шлюбом (ОЗШ),опитувальник, розроблений В.В.Століним, Т.Л.Романовою, Г.П.Бутенко. Зведені результати знаходяться у таблиці 15 для жінок I ЕГ та II ЕГ.

Таблиця 15.

\section{Зведені результати опитування задоволеності шлюбом}

\section{для жінок I ЕГ та II ЕГ}

\begin{tabular}{|c|c|c|c|c|c|}
\hline \multirow[t]{2}{*}{ Показники } & \multicolumn{2}{|l|}{$\mathrm{I} E \Gamma$} & \multicolumn{2}{|c|}{ II EГ } & \multirow{2}{*}{$\begin{array}{l}\text { t-критерій Стьюдента } \\
\text { для непов’язаних } \\
\text { сукупностей } \\
(\text { tкрит=1,992, } \mathrm{f}=76 \text { при } \\
\alpha=0,05)\end{array}$} \\
\hline & $\begin{array}{c}\text { Абс. } \\
\text { кількість }\end{array}$ & $\%$ & $\begin{array}{c}\text { Абс. } \\
\text { кількість }\end{array}$ & $\%$ & \\
\hline $\begin{array}{c}\text { Абсолютно } \\
\text { неблагополучний }\end{array}$ & 2 & 5,3 & 1 & 2,5 & 7,07 \\
\hline Неблагополучний & 6 & 15,8 & 6 & 15,0 & 0,00 \\
\hline $\begin{array}{c}\text { Швидше } \\
\text { неблагополучний }\end{array}$ & 4 & 10,5 & 7 & 17,5 & 21,21 \\
\hline Перехідний & 3 & 7,9 & 7 & 17,5 & 28,28 \\
\hline $\begin{array}{c}\text { Швидше } \\
\text { благополучний }\end{array}$ & 12 & 31,6 & 8 & 20,0 & 28,28 \\
\hline Благополучний & 8 & 21 & 6 & 15,0 & 14,14 \\
\hline $\begin{array}{c}\text { Абсолютно } \\
\text { благополучний }\end{array}$ & 3 & 7,9 & 5 & 12,5 & 14,14 \\
\hline Всього & 38 & 100 & 40 & 100 & \\
\hline
\end{tabular}


За тестом «Задоволеність шлюбом» для жінок I ЕГ маємо результати: у 2 жінок абсолютно неблагополучний шлюб. У 6 жінок отримали неблагополучний шлюб, у 4 жінок маємо швидше не благополучний шлюб. У 3 жінок перехідний шлюб, у 12 жінок швидше благополучний шлюб. У 8 жінок благополучний шлюб і у 3 жінок абсолютно благополучний шлюб.

За тестом «Задоволеність шлюбом» для жінок II ЕГ маємо результати: у однієї жінки абсолютно неблагополучний шлюб, у 6 жінок неблагополучний шлюб, у 7 жінок швидше неблагополучний шлюб. Перехідний шлюб у 7 жінок, у 8 жінок швидше благополучний шлюб. У 6 жінок швидше благополучний шлюб, у 5 жінок абсолютно благополучний.

Висновки та перспективи подальших досліджень. Зрілі жінки, мабуть, частіше роблять правильні висновки з попередньої невдачі, тому вибирають для другого шлюбу адекватнішого партнера або поводяться розумніше й тактовніше. Жінка виступає як організатор свого життя. Індивідуальність життя полягає в здатності жінки організувати його за своїм бажанням, відповідно до своїх інтересів, прагнень, здібностей.

Жінка не повинна ігнорувати власну роль у виникненні конфлікту, цілком перекладаючи вину на чоловіка, як це було в колишньому шлюбі. Виправлення ситуації, що склалася, може вимагати застосування систематичної групової психотерапії.

Жінка має попередити потенційного нового чоловіка, що має дитину від попереднього шлюбу, не робити $з$ цього таємницю. Життя 3 дитиною вимагає зміну всіх колишніх звичок для нового чоловіка, йому доведеться звикнути до того, що вже не буде такого особистого простору, як раніше.

Найскладніша ситуація виникає тоді, коли батько бере активну участь у житті дитини. Рідкісні випадки, коли два чоловіки - колишній чоловік і нинішній - уміють домовитися. Тому жінці доведеться взяти на себе роль посередника.

Потрібно допомогти новому чоловікові примиритися з тим, що рідний батько дитини допомагає іiі малюкові, будь то фінансові вкладення або 
проведення часу 3 дитиною. У той же час ій варто дати зрозуміти колишньому чоловікові, що тепер іiі новий чоловік теж має право на прийняття рішень щодо нової сім'ї в цілому, тобто і щодо дитини теж.

Отже, жінка має бути стійкою, врівноваженою, емоційно зрілою особистістю, яка знає чого хоче від стосунків, від життя. Жінка повинна вміти аналізувати свою поведінку і вчасно звертатися за консультацією до психолога в разі необхідності. Інакше, дуже висока доля імовірності, що в новому шлюбі все піде по старому сценарію.

\section{Список використаних джерел}

1. Голод С. І. Стабільність сім’ї: соціологічний і демографічний аспекти / С. І. Голод.- Л.: Наука, 1984.- 156 с.

2. Ковальов С. В. Психологія сімейних стосунків / С. В. Ковальов.- М.: Педагогіка, 1987.- 208 с.

3. Обозова А. М. Подружня сумісність - фактор стійкості шлюбу / А. М. Обозова //Особистість в системі суспільних відносин.- Ч. 4.- М., 1983.-101 с.

4. Пейдж С. Подружнє життя: шлях до гармонії/С.Пейдж.- М.,1995.-206 с.

5. Роджерс К. Психологія подружніх стосунків / К. Роджерс.- М.:Ексмо. 2002. $-288 \mathrm{c}$.

6. Столярчук О. А. Психологія сучасної сім’ї: навч.посібник / О. А. Столярчук. - Кременчук: ПП Щербатих О. В., 2015.- 136 с.

7. Титаренко Т. М. Життєвий світ особистості: у межах і за межами буденності / Т М. Титаренко. - К.: Либідь, 2003. - 376 с.

8. Федоренко Р. П. Психологія сім’ї : навч. посіб. / Р. П. Федоренко; Східноєвроп. нац. ун-т ім. Лесі Українки. - Луцьк : Вежа-Друк, 2015. - 362 с.

\section{References}

1. Holod, S. I. (1984), Stabil'nist' sim"yi: sotsiolohichnyy i demohrafichnyy aspekty [Stability of the Family: Sociological and Demographic Aspects ], Nauka, L., Russia. 
2. Koval'ov, S. V. (1987), Psykholohiya simeynykh stosunkiv [Psychology of Family Relations], Pedahohika, Moscow, Russia.

3. Obozova, A. M. (1983), "Marital compatibility - the factor of the stability of marriage", Osobystist'v systemi suspil'nykh vidnosyn, vol. 4., Moscow, Russia.

4. Peydzh, S. (1995), Podruzhnye zhyttya: shlyakh do harmoniyi [Married Life: The Way to Harmony], Moscow, Russia.

5. Rodzhers, K. (2002), Psykholohiya podruzhnikh stosunkiv [Psychology of marital relationships], Eksmo, Moscow, Russia.

6. Stolyarchuk, O. A. (2015), Psykholohiya suchasnoyi sim"yi: navch.posibnyk [Psychology of the modern family: teaching guide], PP Shcherbatykh O. V., Kremenchuk. Ukraine.

7. Tytarenko, T. M. (2003), Zhyttyevyy svit osobystosti: u mezhakh i za mezhamy budennosti [The life world of personality: within and beyond the ordinary], Lybid', Kyiv, Ukraine.

8. Fedorenko, R. P. (2015), Psykholohiya sim"yi : navch. posib. [Psychology of the family: educator. manual], Skhidnoyevrop. nats. un-t im. Lesi Ukrayinky, Vezha-Druk, Luts'k, Ukraine. 